Book Review

\title{
Evans, C. Stephen, Kierkegaard on Faith and the Self: Collected Essays
}

\section{Robert C. Cheeks}

G iven the spiritual disorder of our age, the ever-present pneumopathology of consciousness, we might be forgiven for being a bit confused, anxious, and just a little depressed. Consequently, it falls to each of us to ignore the "autonomous" philosophers, who are in reality the closed system philodoxers (sophists) demanding the end to the quest and search those dusty old tomes wherein we might stumble across order, truth, and a suggestion or two on just how to address the "reflective action" inherent in the concrete human being. To be sure the quest is a formidable challenge, but no one said life is easy, after all Plato, Aristotle, and Socrates had to contend with their own Sophists!

So, if you are inclined to engage in the act of philosophizing, you should understand that a real philosopher is one "whose psychic sensorium responds to eternal being." 2 And, to make a finer point, Ellis Sandoz of Louisiana State University, wrote, "A (second) consequence is plainly a substantial, even revolutionary redefinition of the meaning of philosophy itself, especially in the decisive points of: (a) underling the loving tension toward the divine Reality in open existence as central; (b) attenuating or abandoning the Scholastic convention separating faith and reason as supernatural and natural, respectively; and (c) discarding as egophany (defiant self assertion claiming independence from a transcendent ground) the arrogant pretense of autonomous reason as its originator in self-sufficient human speculators."3

One philosopher who adheres in many ways to Sandoz's revolutionary definition, is Soren Kirkegaard, often identified as the "father of existentialism." And, a book that both broadly and deeply explores the philosophy and theology of Soren Kierkegaard is Baylor University Professor of Philosophy, C. Stephen Evans's Kierkegaard: On Faith and the Self, Collected Essays (Baylor University Press, 2006).

Evans tells us that Kierkegaard's project was to challenge not only the Danish government in its establishment of a national religion, thereby deemphasizing personal responsibility for one's own soul, and “to legitimize the

\footnotetext{
1 Waco: Baylor University Press, 2006. 385 pp.

2 See Eric Voegelin, "Eternal Being in Time," in Anamnesis (Missouri: University of Missouri Press, 1990)

${ }^{3}$ See Ellis Sandoz, "The Philosophers Vocation: The Voegelinian Paradigm," in Essays from the APS A Annual Meeting, Eric Voegelin Society, (2007), 1.
} 
status quo of an emerging bourgeois culture," 4 but also to challenge the notion that Europeans of his era were intellectual giants rather than "imaginative midgets, lacking the deep 'passions' that make human life worth living." 5

Significantly, the "challenge" in which Kierkegaard engaged was a critical response to the formidable Enlightenment philosopher Georg W. F. Hegel and his claim of developing a "system" that had the deleterious effect of bringing philosophical discourse to "finality." Kierkegaard vehemently denied not only Hegel's systemic pomposity but also his hubristic efforts to defend Christianity in an objective language.

Evans has segregated his book into six parts of three to five essays each. The "parts" each develop a pertinent theme: Part One is the Introduction, Part Two: Kierkegaard the Philosopher, Part Three: Kierkegaard on Faith, Reason, and Reformed Epistemology, Part Four: Kierkegaard on Ethics and Authority, Part Five: Kierkegaard on Self: Philosophical Psychology, and Part Six: the Conclusion.

The critical argument that the author puts forth is that Kierkegaard has, by and large, been misread. That our assumed understanding of the philosopher's project are, in fact, "misinterpretations," caused in large measure by the French existentialist, Albert Camus. Evans's project is to examine the notion that Kierkegaard is an "irrationalist" both in terms of beliefs and choice. "At the same time that I dispel the myths about Kierkegaard the irrationalist," Evans writes, "I must clear the way to hear the Kierkegaard who demands that we reject the view that human reason is a timeless godlike faculty. Instead of talking about Reason, we need to focus on the actual reasoning of historically situated, subjectively conditioned, finite human beings." 6

Evans describes Kierkegaard as "perhaps the greatest Christian thinker since the Middle Ages."' One example is Kierkegaard's critique of Hegel's response to Kantian skepticism, where he argues that human beings are indeed capable of "knowledge of the external world" but only by incorporating "faith or belief." The author explains that Kierkegaard shows that the only objective truth the person may know "as actual" is his own reality, that "the actuality of those other realities that is believed" “"approximative' type of knowledge."10

It is here Kierkegaard brilliantly establishes the boundary of noetic consciousness as the person moves into a mode of pneumatic differentiation in his search for the divine. Kierkegaard has shown that even at the extreme pole of the immanent world-reality the truth of existence requires fides and that fundamental requirement points us toward the transcendent. Kierkegaard's critique of Hegel's response to Kantian skepticism illuminates the flaws in

\footnotetext{
${ }^{4}$ Evans, op cit., 4

${ }^{5}$ Ibid., 5

${ }^{6}$ Ibid., 8.

${ }^{7}$ Ibid., 9.

${ }^{8}$ Ibid., 40-1.

${ }^{9}$ Ibid., 41.

${ }^{10}$ Ibid.
} 
Hegel's closed system which inevitably collapses under the weight of what in reality is a egophanic revolt.

Evans shows that at the core of Kierkegaard's theology is a rejection of the idea that we may objectively "know" God. Faith, or belief, is another matter. "But note," Evans writes, "that the recognition of the "subjective" grounds of the belief in no way entails that the content of the belief must be subjective." 11

Therefore, the process of belief in God has its beginnings in the noetic exegesis that may be partially constituted by objectivity. However, it is within the pneumatic differentiation that the spiritual irruption occurs where the individual begins to develop a consciousness that is attracted to and seeks the metaleptic reality of communion with God. This communion of being and God is achieved by means of prayer or mediation, occurring in the Metaxy, in a state of "ascent through the via negativa"12 — where one seeks "immunity" from the collapse of order and the distortions inherent in the immanent worldreality.

Evans provides in-depth explications of Kierkegaard's use of the role of irony and humor, as well as a critique of the misuse of language, foundationalism, and the role of historical criticism in the examination of the Christian faith. His essays on Kierkegaard that include a comparative examination of the project of the reform theologian/philosopher Alvin Plantinga, were my personal favorites and clearly illustrates the author's talent at relating complex ideas for the lay reader.

The penultimate Part Five, Kierkegaard on the Self: Philosophical Psychology, present four essays that brilliantly examine and explicate the human person in terms of "neighborly love," Kierkegaard's famous "leap of faith," the difficulties inherent in skepticism, and the will as it is predicated on our "desires and passions."

Kierkegaard tells us that God initiates this communion between being and God within the psyche. "It is the experience of meeting God," Evans writes, "which produces the passion of faith...Such an encounter may properly be said to be the ground of faith without constituting evidence for faith."13 Thus, we have the Kierkegaardian "leap of faith," which in reality is no leap at all because as Evans writes, "The believer both knows what he is leaping to, and why he is leaping."14

In the experience of meeting God the human person must consider the "truth" of his life prior to the theophanic event. Evans argues that, "The encounter with the God in time makes it possible for an individual to recognize the bankruptcy of autonomous reason, but it does not make it necessary. What

${ }^{11}$ Ibid., 62.

12 See Stefan Rossbach, "Understanding in Quest of Faith: The Central Problem in Eric Voegelin's Philosophy," in Essays from the APSA Annual Meeting, Eric Voegelin Society (2007), 10 .

${ }^{13}$ Evans, op cit., 128.

${ }^{14}$ Ibid., 129. 


\section{KIERKEGAARD ON FAITH AND THE SELF}

is necessary is the relinquishment of pride and the acquisition of humility." 15 This "relinquishment of pride" is the voluntary surrender of self, as an act of will, to the Creator. It is being rejecting the libido dominandi in order to do God's Will and it constitutes one of two essential transcendent acts required of man in order to move beyond the structure of the immanent world-reality to a "state of aphtharsia or imperishing." 16

For Kierkegaard the most radical expression of human experience is the Incarnation-God made man. The Incarnation is the ultimate act of God's healing, where as Catholic University philosophy professor, Msgr. Robert Sokolowski wrote, "the divine Logos assumes a full human nature that was not diminished in any way through its union with the Word. Human nature, as well as human reason, is healed, not replaced or overcome, by its union with the word of God."17

Kierkegaard referred to the Incarnation as both an "absolute paradox" and an "offense" to those whose existence lay only in the spatio-temporal reality dominated as it is by ideological distortion. However, the Incarnation, symbolizing a pneumatic differentiation within the psyche-the place of actualization for the human/divine relationship-represents, "truth emerging in the process of history," 18 coming into existence in both the immanent-world reality and the theophanic process.

The fides experienced in the truth in reality of the Incarnation-the most singular event in history- can generate additional insights that transcend the experience of the initial pneumatic differentiation, dependent of course on the will and pneumatic acuity of the person participating. This experience, of loving God and being loved by God, knows no boundaries in time or eternity; it exists in time and the timeless. It is the existence of being in grace.

Evans argues that Kierkegaard's concern was not to defend the "reasonableness" or unreasonableness of Christianity but rather "to argue the impossibility of neutrality. When reason encounters the paradox, faith and offense are both possible; what is not possible is indifference." 19

Evan's Kierkegaard on Faith and the Self: Collected Essays is an erudite and provocative examination of the philosopher's project that rejects those modern critiques that have distorted Kierkegaard's work. Evans shows that Kierkegaard successfully challenged the distortions initiated by the Enlightenment project, that he was intimately aware of the limits of human reason, and that he shared with the classical philosophers an understanding of the structure of reality as existing in tension with eristics, the "climate of opinion," and Hegelian dialectics. Kierkegaard boldly rejected the death of

\footnotetext{
15 Ibid., 130.

${ }^{16}$ See Collected Works of Eric Voegelin, Vol. 34 (Missouri: University of Missouri Press, 2006), 151

17 Robert Sokolowski, "Philosophy and the Christian Act of Faith," in Christian Faith and Human Understanding (Washington: Catholic University of America Press, 2006), 36.

18 See "Truth and History," in Collected Works of Eric Voegelin, Vol. 17 (Missouri: University of Missouri Press, 2000), 316-21.

${ }^{19}$ Evans, op cit., 131.
} 


\section{R. CHEEKS 153}

God demanded by modernity and instead explicated the divine purpose of man. In essence he became the "viator in the Christian sense" 20 seeking the truth of reality within an eschatological denouement in communion with God.

Robert C. Cheeks is an independent scholar from Lisbon, Obio, United States

\section{References}

Evans, C. Stephen, Kierkegaard on Faith and the Self: Collected Essays (Waco: Baylor University Press, 2006).

Rossbach, Stefan, "Understanding in Quest of Faith: The Central Problem in Eric Voegelin's Philosophy," in Essays from the APS A Annual Meeting, Eric Voegelin Society (2007).

Sandoz, Ellis, "The Philosophers Vocation: The Voegelinian Paradigm," in Essays from the APS A Annual Meeting, Eric Voegelin Society, (2007).

Sokolowski, Robert, "Philosophy and the Christian Act of Faith," in Christian Faith and Human Understanding (Washington: Catholic University of America Press, 2006).

Voegelin, Eric, "Eschatology and the Philosophy: The Practice of Dying," in Collected Works of Eric Voegelin, Vol. 34 (Missouri: University of Missouri Press, 2006).

"Eternal Being in Time," in Anamnesis (Missouri: University of Missouri Press, 1990).

"Truth and History," in Collected Works of Eric Voegelin, Vol. 17

(Missouri: University of Missouri Press, 2000).

20 See "Eschatology and the Philosophy: The Practice of Dying," in Collected Works of Eric Voegelin, Vol. 34 (Missouri: University of Missouri Press, 2006), 147. 